\title{
Microorganisms screening for limonene oxidation
}

\author{
Seleção de microrganismos para oxidação de limoneno
}

\section{Lindomar LERIN ${ }^{1}$, Geciane TONIAZZO $^{2}$, Débora de OLIVEIRA ${ }^{2 \star}$, Leda ROTTAVA ${ }^{1}$, Cláudio DARIVA³ Rogério Luis CANSIAN ${ }^{2}$, Helen TREICHEL ${ }^{2}$, Francine PADILHA ${ }^{3}$, Octávio Augusto Ceva ANTUNES ${ }^{1}$}

\begin{abstract}
Limonene is a monoterpene obtained in large amounts from essential oils and is used as a raw material for the synthesis of flavors and fine chemicals. Several pathways or routes for the microbial degradation of limonene making use of the cytochrome P450-dependent monooxygenases have been described. In this study, we present a fermentative screening of microorganisms in order to verify their ability to perform the desirable conversion. In parallel, the PCR technique was used to select the microorganisms that contain the lim $\mathrm{C}$ gene, which is responsible for the conversion of carveol to carvone. The microorganisms selected by PCR were not able to bioconvert limonene. From this result, we can suppose that these strains do not have the gene that codifies the enzyme responsible for the transformation of limonene into carveol. The results obtained in the fermentative screening showed that 4 microorganisms were able to bioconvert limonene into carveol. In addition, the amplification results showed the presence of fragments of $800 \mathrm{pb}$, expected for the $\lim C$ gene. Therefore, the results obtained in the bioconversion and evaluation of the $\lim C$ gene did not allow a correlation showing that these strains do not contain all the enzymes responsible for the conversion of limonene to carvone.
\end{abstract}

Keywords: $\mathrm{CDH}$ (carveol dependent dehydrogenase); carveol; carvone; PCR; fermentative screening.

\section{Resumo}

O limoneno é um monoterpeno obtido em grandes quantidades a partir de óleos essenciais, podendo ser utilizado como matériaprima na síntese de flavours e compostos para química fina. Várias rotas para a degradação microbiológica do limoneno fazendo uso da monoxigenase dependente do citocromo P450 têm sido propostas. Neste trabalho, são apresentados dados obtidos no screening fermentativo de microrganismos visando verificar suas habilidades em realizar a conversão desejada. Em paralelo, a técnica do PCR foi também utilizada visando selecionar microrganismos que apresentam o gene $\lim \mathrm{C}$, responsável pela conversão de carveol a carvona. Os microrganismos selecionados por PCR não foram capazes de bioconverter o limoneno. A partir dos resultados obtidos pode-se supor que estas cepas não possuem o gene que codifica a enzima responsável pela etapa de transformação do limoneno a carveol. Os resultados obtidos no screening fermentativo mostraram que 4 microrganismos foram capazes de bioconverter o limoneno. Além disso, o resultado da amplificação mostrou a presença de fragmentos de 800 pb, esperados para o gene $\lim C$. Desta forma, os resultados obtidos na bioconversão e avaliação do gene $\lim C$ gene não permitiram obter uma correlação, mostrando que as cepas testadas não possuem todas as enzimas responsáveis pelas etapas de conversão do limoneno a carvona.

Palavras-chave: CDH (dehidrogenase dependente do carveol); carveol; carvona; PCR; screening.

\section{Introduction}

The essential oils are a source of volatile terpenes, substances widely distributed in nature. Spearmint (Mentha spicata) and peppermint (Mentha piperita) are species used for the commercial production of essential oils. Their distinct characteristics are based on the oxygenation position of the constituent monoterpenoid $\rho$-mentane. Peppermint produces almost exclusive monoterpenes with oxygen $\mathrm{C} 3$ position (such as (-)-menthol, which is responsible for the cold sensation of the peppermint). The spearmint produces a monoterpene with oxygen at the C6 allylic position (such as (-)-carvone, which is responsible for the typical note of the spearmint) (LAWRENCE, 1981). The precursor olefin of the bioconversion reaction,
(-)-4S-limonene, is hydroxylated exclusively at C3 position producing (-)-trans-isopiperitenol, which is subsequently converted into a complex mixture of compounds of peppermint oil. In spearmint, the limonene is hydroxylated exclusively at C6 position producing (-)-trans-carveol and, following the oxidation, (-)-carvone. This region-specific hydroxylation is mediated by two cytochrome $\mathrm{P} 450$ enzymes, limonene6-hydroxylase (CYP71D18) and limonene-3-hydroxylase (CYP71D13) (SCHALK; CROTEAU, 2000).

Kubota et al. (2005) showed that the cytochrome P450 (CYP153A), heme alkane hydroxylase, from Alcanivorax sp.

Recebido para publicação em 16/4/2008

Aceito para publicação em 4/1/2009 (003440)

${ }^{1}$ Departamento de Bioquímica, Instituto de Química, Universidade Federal do Rio de Janeiro - UFRJ, CEP 21949-900, Cidade Universitária, Rio de Janeiro - RJ, Brasil

${ }_{2}^{2}$ Departamento de Engenharia de Alimentos, Universidade Regional Integrada - URI, Campus de Erechim, CEP 99700-000, Av. Sete de Setembro, 1621, Erechim, RS, Brasil,

E-mail: odebora@uricer.edu.br

${ }^{3}$ Instituto de Pesquisa e Tecnologia, Universidade Tiradentes - UNIT, CEP 49032-490, Campus Farolândia, Av. Murilo Dantas, 300, Aracaju - SE, Brasil

${ }^{*}$ A quem a correspondência deve ser enviada 
mediates the oxidation reactions of various hydrocarbons, including not only $\mathrm{n}$-alkanes but also a cycle-alkane and aromatic hydrocarbons. This P450 gene was also used as a scaffold in the study in order to build the 5'-and 3'-arm segments for cassette Polymerase Chain Reaction (PCR) for expressing functionally new P450 genes isolated from various environments. Escherichia coli cells expressing these self-sufficient $\mathrm{P} 450$ chimerical genes able to convert $n$-alkanes, cycle-hexane, 1-octene, $n$-butylbenzene, and 4-phenyl-1-butene to 1-alkanols, cycle-hexanol, 1,2-epoxyoctane, 1-pheny-4-butanol, and 2-phenethyl-oxirane, respectively. Many studies have been carried out about the oxygenases cytochrome P450 SINCE these enzymes play an important role in the metabolism of the terpenoids mould and stabilize the oxygenation of many types of carbon skeleton, These enzymes begin the subsequent redox transformation and reactions of the conjugated that contribute significantly for the structural diversity and the great number of natural products derivative of this class (LUPIEN et al., 1999).

Cytochrome P450-dependent hydroxylases play a pivotal role in the biosynthesis of several hundred naturally occurring oxygenated monoterpenes (e.g., menthol, carvone, thujone, pinocamphone), which are largely responsible for the flavor and fragrance of plant-derived essential oils (BAUER; GARBE; SURBURG, 1990). Most oxygenated monoterpenes are formed by the initial cyclization of the precursor geranyl-diphosphate to an olefin that defines the structural family of the metabolites produced, followed by the regio- and stereoespecifc cytochrome P450-dependent allylic hydroxylation of the parent olefin, which determines the oxygenation pattern of the derived metabolites (KARP; CROTEAU, 1988).

Several pathways for the microbial degradation of limonene have been described so far, but most of them have not been substantiated by biochemical studies. The best studied microbial degradation pathway for limonene involves the hydroxylation at the $\mathrm{C}_{7}$-methyl group resulting in the formation of perillyl alcohol. Two enzymes of this pathway, perillyl alcohol dehydrogenase and perillyl aldehyde dehydrogenase, have been partially purified (BALLAL; BHATTACHARYYA; RANGACHARI, 1967, 1968; DHAVALIKAR; BHATTACHARYYA, 1966; TRUDGILL, 1986). Another proposed pathway mentions that the conversion of carveol to carvone is performed by the carveol dehydrogenase (CDH) (van der WERF; SWARTS; de BONT, 1999).

Isolated Rhodococcus erythropolis DCL14 (van der WERF; SWARTS; de BONT, 1999), a strain able to grow on limonene as sole carbon and energy source that contains a novel degradation pathway for limonene. Cells grown on limonene and carveol were found to contain a DCPIP-dependent carveol dehydrogenase $(\mathrm{CDH})$ that converts carveol into carvone. The $R$. erythropolis $\mathrm{CDH} \lim \mathrm{C}$ gene was identified in an operon encoding the enzymes involved in limonene degradation. The $\mathrm{CDH}$ nucleotide sequence revealed an open reading frame of 831 base pairs (bp) encoding a 277 -amino acid protein with a deduced mass of 29,531 Da.

In this report, we describe the development of a biotechnological process of alyllic oxidation of limonene by screening microorganisms so as to verify the ability to perform the desirable conversion. In parallel, the PCR technique was also used to select the microorganisms that contain the $\lim \mathrm{C}$ gene, responsible for the conversion of carveol to carvone.

\section{Materials and methods}

\subsection{Cell production}

A total of 17 microorganisms were used in this study. The strains of microorganisms belonging to different genera were obtained from different institutions, as shown in Table 1. All the strains were generously supplied by those respective institutions. Table 1 also presents the culture medium used for each microorganism. Fungi were cultivated in PD, YM, Malt, and Czapek Dox at $25^{\circ} \mathrm{C}$ for 72 hour; except for Paecilomyces variotii that was cultivated for 120 hours. Yeasts were cultivated in $\mathrm{YM}$ at $25^{\circ} \mathrm{C}$ for 24 hours and the bacteria were cultivated in $\mathrm{LB}$ at $28^{\circ} \mathrm{C}$ for 24 hours. Stock cultures of organisms were maintained in medium slants and stored at $4{ }^{\circ} \mathrm{C}$ after growth.

\subsection{Screening experiments}

For the biotransformation experiments, the reactions were started 3 days after inoculation for the fungi and 24 hours for bacteria and yeasts by adding $300 \mu \mathrm{L}$ of the substrate directly to the culture flasks with $30 \mathrm{~mL}$ of medium. The substrates were added as solutions in absolute ethanol $(1: 1 \mathrm{v} / \mathrm{v})$. It was used $1 \%(\mathrm{v} / \mathrm{v})$ of substrate in $1 \%(\mathrm{v} / \mathrm{v})$ of $\mathrm{EtOH}$, at $25^{\circ} \mathrm{C}$ and $150 \mathrm{rpm}$ for 6 days in all experiments. The media and cultivation time used for each microorganism are presented in Table 1. All experiments were carried out in parallel with controls and under the same experimental conditions without the presence of microorganism. The experiments (duplicate runs were conducted for each experimental condition) were performed for each microorganism in closed stoppered glass flasks in order to avoid the evaporation of the substrate and product.

\subsection{Extraction and identification of biotransformation products}

The cells were removed by filtration for fungi and centrifugation for bacteria and yeasts. The product recovery was performed by liquid-liquid extraction with $3 \times 12 \mathrm{~mL}$ of ethyl acetate $\left(\mathrm{Et}_{2} \mathrm{O}\right)$. After the extraction, the solution volume was completed to $25 \mathrm{~mL}$. The final solution was dried over anhydrous sodium sulphate.

The reaction products were identified by GC/MS (Shimadzu QP5050A) using a capillary column DB-WAX (30 m, $0.25 \mathrm{~mm}$, $0.25 \mu \mathrm{m}$ ). The column temperature was programmed at $50^{\circ} \mathrm{C}$ for 3 minutes, increased by $5{ }^{\circ} \mathrm{C} /$ minute to $130{ }^{\circ} \mathrm{C}$, and then increased by $15{ }^{\circ} \mathrm{C} /$ minute to $210^{\circ} \mathrm{C}$ for 5 minutes. Helium was the carrier gas, and the injection and detector temperatures were both $250^{\circ} \mathrm{C}$. $0.5 \mu \mathrm{L}$ of the dried solution was injected into the GC/MS system. The apparatus operated with a flow rate of $1 \mathrm{~mL} /$ minute in electronic impact mode of $70 \mathrm{eV}$ and in split mode (split ratio 1:10).

The identification of the compounds was accomplished by comparing the mass spectra with those from the Wiley library 
Lerin et al.

Table 1. Microorganisms tested in the screening and composition of different growth media.

\begin{tabular}{|c|c|c|c|}
\hline Code & Microorganism & Culture medium & Time cultivation (hour) \\
\hline 1 & Aspergillus niger ${ }^{1}$ & $\mathrm{PD}^{5}$ & 72 \\
\hline 12 & Aspergillus niger ATCC $9642^{2}$ & $\mathrm{YM}^{6}$ & 72 \\
\hline 17 & Aspergillus oryzae ATCC $1003^{2}$ & $\mathrm{PD}^{6}$ & 72 \\
\hline 3 & Penicillium citrinum ATCC $28752^{2}$ & Malt $^{7}$ & 72 \\
\hline 15 & Penicillium brevicompactum ${ }^{3}$ & $\mathrm{PD}^{5}$ & 72 \\
\hline 29 & Penicillium camembertii (CT) ATCC $4845^{2}$ & $\mathrm{PD}^{5}$ & 72 \\
\hline 31 & Penicillium verrucosum ${ }^{3}$ & $\mathrm{PD}^{5}$ & 72 \\
\hline 33 & Penicillium simplicissimum ${ }^{3}$ & $\mathrm{PD}^{5}$ & 72 \\
\hline 35 & Penicillium duclauxii ATCC $9121^{2}$ & $\mathrm{PD}^{5}$ & 72 \\
\hline
\end{tabular}

${ }^{1}$ Instituto de Microbiologia of the Universidade Federal do Rio de Janeiro (Rio de Janeiro, Brazil), ${ }^{2}$ Fundação Instituto Oswaldo Cruz (Rio de Janeiro, Brazil), ${ }^{3}$ These microorganisms were isolated from the reject of the industry of babassu for Freire, Gomes and Bom (1997) ${ }^{4}$ Laboratório de Biotecnologia Vegetal of the Universidade Regional Integrada (Erechim, Brazil). ${ }^{5} \mathrm{PD}$ (300 g infusion from potates and $20 \mathrm{~g}$ glucose); ${ }^{6} \mathrm{YM}$ ( $3 \mathrm{~g}$ yeast extract, $3 \mathrm{~g}$ malt extract, $5 \mathrm{~g}$ peptone and $10 \mathrm{~g}$ glucose); ${ }^{7} \mathrm{Malte}\left(30 \mathrm{~g}\right.$ malt extract and $3 \mathrm{~g}$ peptone); ${ }^{8} \mathrm{Czapec}$ $\operatorname{Dox}\left(0,5 \mathrm{~g} \mathrm{KCl}, 1 \mathrm{~g} \mathrm{KH}_{2} \mathrm{PO}_{4}, 2 \mathrm{~g} \mathrm{NaNO}, 30 \mathrm{~g}\right.$ sucrose, $\left.0,1 \mathrm{~g} \mathrm{FeSO}_{4} \cdot \mathrm{H}_{2} \mathrm{O}, 0,5 \mathrm{~g} \mathrm{MgSO} \cdot 7 \mathrm{H}_{2} \mathrm{O}\right)$ and ${ }^{9} \mathrm{LB}(10 \mathrm{~g}$ tryptone, $5 \mathrm{~g}$ yeast extract and $10 \mathrm{~g}$ NaCl$)$, all the media were prepared in $1000 \mathrm{~mL}$ of distilled water.

and by additional comparison of the GC retention time of standard compounds.

\subsection{Genomic DNA extraction}

The DNA extraction from bacteria and yeast was performed according to Sambrook, Fritsch and Maniatis (1989) with some modifications. Cultures of each strain were grown according to the conditions presented previously (Table 1) $1.5 \mathrm{~mL}$ of each culture was centrifuged (Eppendorf Centrifuge Model 5403 ) for 5 minutes at $21.467 \times \mathrm{g}$ to collect the bacterial or yeast cells, and the supernatant was discarded. Each pellet was mixed in $600 \mu \mathrm{L}$ of buffer containing $25 \mathrm{mM}$ Tris ([Hydroxymethyl] aminomethanol-Sigma) - HCl, $\mathrm{pH}$ 8.0, $10 \mathrm{mM}$ EDTA (Ethylenediaminetetracetic Acid, Disodium Salt, and Dihydrate- $\mathrm{Na}_{2}$ EDTA.2 $\mathrm{H}_{2} \mathrm{O}-\mathrm{Gibco}$ BRL), and $50 \mathrm{mM}$ glucose were then added and mixed. Next, $50 \mu \mathrm{L}$ of lysozyme (2 mg. $\mathrm{mL}^{-1}$, Sigma) was added, and the mixture was left in repose for 10 minutes. Afterwards, $66 \mu \mathrm{L}$ of $10 \%(\mathrm{~m} / \mathrm{v})$ sodium dodecyl sulfate (SDS) and $3 \mu \mathrm{L}$ of 2 -mercaptoethanol was added to each tube, which was vortexed briefly and then incubated at $65^{\circ} \mathrm{C}$ for 30 minutes.

To each tube, it was added $190 \mu \mathrm{L}$ of $3 \mathrm{M}$ sodium acetate and mixed by inversion. Next, the mixture was incubated for 30 minutes at $4{ }^{\circ} \mathrm{C}$ and then centrifuged for 5 minutes at $21.467 \times \mathrm{g}$. The supernatant containing DNA was precipitated with one volume of ice-cold isopropanol mixed by inversion, incubated at $-20^{\circ} \mathrm{C}$ for 10 minutes, and then centrifuged for 5 minutes at $21.467 \times \mathrm{g}$. The supernatant was discarded and the air dried, and re-suspended in $200 \mu \mathrm{L}$ of TE buffer $(10 \mathrm{mM}$ Tris- $\mathrm{HCl}, \mathrm{pH}$ 8.0, 1 mM EDTA).

The DNA extraction from fungi was based on the methodology developed by Roeder and Broda (1987). Cultures of each strain were grown according to the conditions presented previously (Table 1). Liquid nitrogen was added to $300 \mathrm{mg}$ of mycelia in a mortar, and the cells were ground in a pestle. In sum, the powdered mycelium was transferred to an Eppendorf tube and $700 \mu \mathrm{L}$ of buffer (3\% (v/v) SDS, $50 \mathrm{mM}$ EDTA, $50 \mathrm{mM}$ Tris-HCl, pH 8.0, and 1\% (v/v) 2-mercaptoethanol) were added. Each sample was incubated for 1 hour at $65^{\circ} \mathrm{C}$. Then, the tubes content were removed and cooled, extracted with an equal volume of chloroform-isoamyl alcohol (24:1), and centrifuged at $21.467 \times \mathrm{g}$ for 10 minutes. This procedure was repeated three times. After this, it was added $120 \mu \mathrm{L}$ of $3 \mathrm{M} \mathrm{pH} 5.2$ sodium acetate and $600 \mu \mathrm{L}$ of ice-cold isopropanol mixed by inversion. The mixture was incubated in a freezer for 30 minutes and centrifuged for 5 minutes at $21.467 \times \mathrm{g}$. The DNA precipitate was re-suspended in 500 to $700 \mu \mathrm{L}$ of TE buffer, washed twice in $500 \mu \mathrm{L}$ of $70 \%$ ethanol, air dried, and re-suspended in $200 \mu \mathrm{L}$ of TE buffer.

\subsection{DNA quantification}

For the evaluation of DNA concentration, $1000 \mu \mathrm{L}$ of water MilliQ sterile were added in an assay tube and $20 \mu \mathrm{L}$ of sample. The DNA concentration was estimated by measuring the optical density at $260 \mathrm{~nm}$ using a spectrophotometer (Agilent 8453) and checked by electrophoresis on a $0.8 \%$ agarose gel (Gibco BRL)

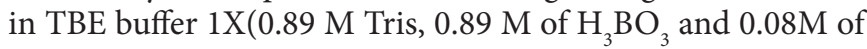
EDTA).

\subsection{PCR amplification reaction}

The PCR reactions were conducted in total volumes of $25 \mu \mathrm{L}$. The reaction mixture contained $50 \mathrm{mM}$ Tris- $\mathrm{HCl}$ pH 9.0 buffer; $50 \mathrm{mM} \mathrm{KCl} \mathrm{(Life} \mathrm{Technologies,} \mathrm{São} \mathrm{Paulo,}$ Brazil), dNTPs mix (200 mM of each nucleotide (Life 
Technologies, São Paulo, Brazil)), 10 pmol of the primer 1 (GGGACAATGGCAAGAGTAGAA), and 10 pmol of the primer 2 (TCCTGCATCGACGGGAAT) (these primers were selected to design the sequence obtained at GenBank for the $\lim \mathrm{C}$ gene), $3 \mathrm{mM}$ of $\mathrm{MgCl}$, 1,5 U of Taq DNA polymerase, Recombinant Invitrogen (Life Technologies, São Paulo, Brazil), and $40 \mathrm{ng}$ of DNA.

\subsection{PCR amplification}

The amplification was performed in a thermal cycler, MJ Research Inc., Watertown, MA (model PTC100TM Programmable Thermal Controller) as follows: one initial cycle for three minutes at $94^{\circ} \mathrm{C}$, followed by 40 cycles for 1 minute at $94{ }^{\circ} \mathrm{C}, 1$ minute at $50{ }^{\circ} \mathrm{C}$ and 2 minutes at $72{ }^{\circ} \mathrm{C}$ and one cycle of 5 minutes at $72{ }^{\circ} \mathrm{C}$ followed by cooling at $4{ }^{\circ} \mathrm{C}$.

\subsection{Electrophoresis of the amplifying fragments}

The amplification products were separated by electrophoresis in $1.4 \%$ agarose gels in buffer TBE $1 \mathrm{X}(0.89 \mathrm{M}$ Tris, $0.89 \mathrm{M}$ of $\mathrm{H}_{3} \mathrm{BO}_{3}$ and $0.08 \mathrm{M}$ EDTA) in a horizontal electrophoresis cube. The run was performed with constant voltage of $90 \mathrm{v}$. DNA Lambda digested with EcoRI and Hind III of the Gibco
BRL was included as a molecular size marker. The gels were visualized by staining with ethidium bromide and the banding patterns were photographed under UV light. The gels were photographed using the digital system photographic GEL-PRO (Media Cybernetics, Silver Spring, MD).

\subsection{DNA extraction of gel}

The material amplified by PCR was extracted from the gel using the QIAquick (Gel Extraction Kit (Quiagen $\left.{ }^{\circledast}\right)$ ) kit and estimated on agarose gel $0.8 \%$.

\section{Results and discussion}

A screening by fermentative process was performed in order to select the strains able to convert limonene into oxygenated products, especially carvone.

Limonene was one of the first terpenic compounds used in biotransformation studies. Dhavalikar and Bhattacharyya (1966) proposed three routes (Figure 1) for the biotransformation by microorganisms ( $\mathrm{a}, \mathrm{b}$ and $\mathrm{c}$ ). Later, a new route was proposed by Kraidman et al. (1969) and evaluated by Kraidman, Mukherjee and Hill (1986) for the biotransformation by filamentous

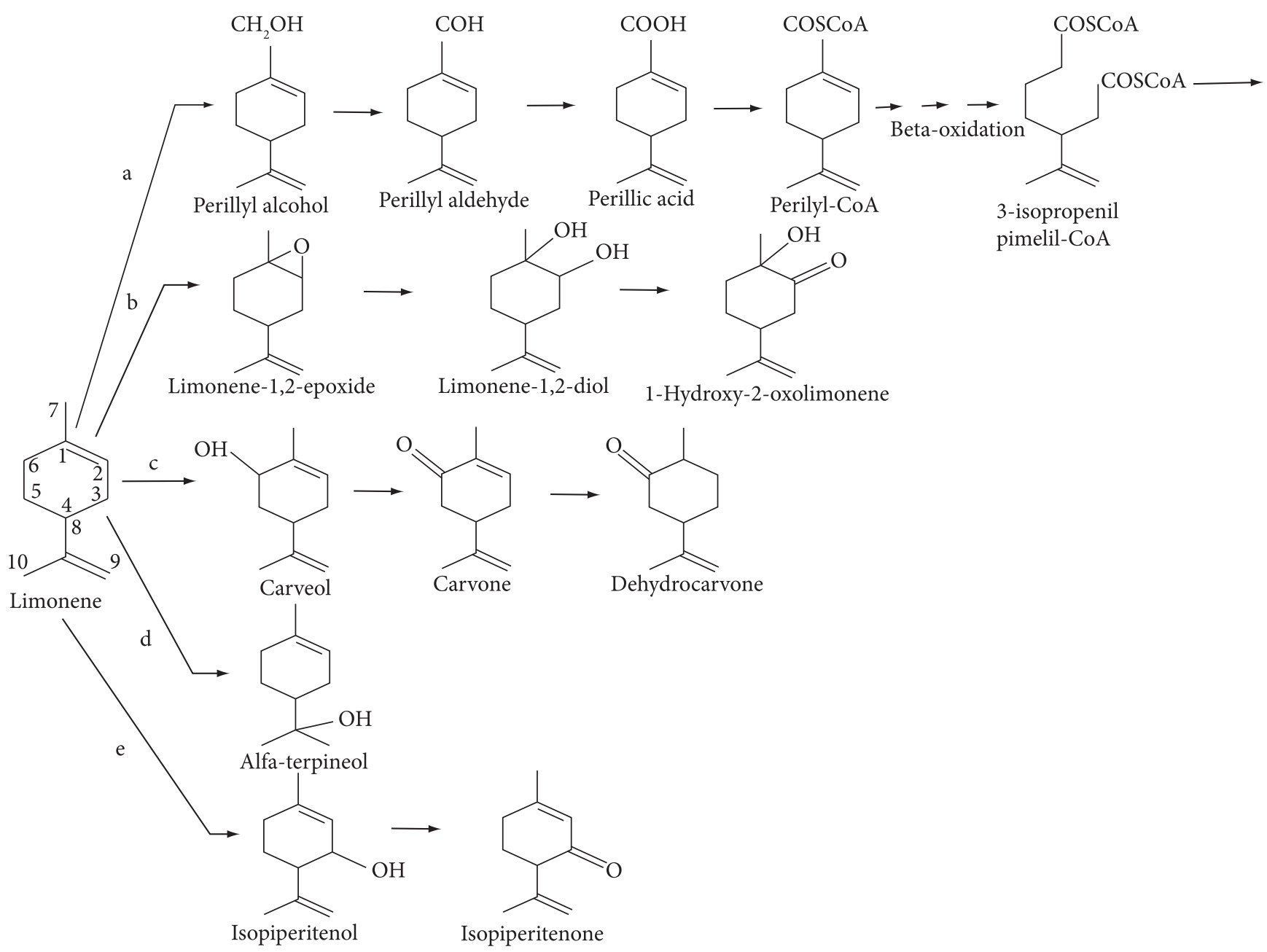

Figure 1. Proposed routes for limonene biotransformation by microorganisms. 
fungus (d). van der Werf; Swarts and de Bont, (1999) studied another route (e) which shows the bioconversion of limonene to isopiperitenol and then, to isopiperitenone.

Kieslich et al. (1986) presented the results of an extensive research, in which 800 strains of many microorganism species were tested in relation to their potencial use in the biotransformation of terpenic compounds. The authors observed that 320 strains were able to convert limonene into products of known metabolic ways.

Chang and Oriel (1994) isolated a thermophilic bacterium from orange peel, Bacillus stearothermophilus supposing it was adapted to limonene, the main component from the orange peel oil. Perylic alcohol and $\alpha$-terpineol were identified as major biotansformation products; nevertheless many other products were also obtained. The obtention of several products is not desirable in a bioconversion resulting in high separation costs and lower conversion for the product of interest.

The limonene transformation by Pleurotus sapidus to cis/ trans-carveol and carvone was performed by cultivation of precultures in the presence of limonene obtaining a conversion of 1.2 and $0.8 \%$, respectively (ONKEN; BERGER, 1999).

Based on the results presented in the literature, one can observe that there are many studies related to the limonene bioconversion; nevertheless, references about a systematic study to obtain better selectivity and conversions are scarce in the literature. Due to these aspects, in the present work, the PCR technique was also used with the main objective of selecting strains that present the $\lim \mathrm{C}$ gene, responsible for conversion of carveol to carvone, for a further study of over expression. The ability, versatility, and sensitivity of PCR make this technique interesting for genetic-molecular studies involving many individuals of any live organism. Many traditional methods of cloning, sequencing, and the polymorphism analysis of DNA were accelerated or substituted by using the various forms of PCR techniques.

\subsection{Screening experiments}

After the screening experiments, some strains were able to perform the desired biotransformation. Table 2 shows the microorganisms that presented ability for transformation, the end products, and the reaction conversion (\%) obtained in relation to the normalized peak areas. The strains selected were Aspergillus niger, Penicillium simplicissimum, Aspergillus niger ATCC 9642, and Pseudomonas putida.

The metabolites recovered were $a$-terpineol and cyclehexanemethanol for $A$. niger, a-terpineol for $A$. niger ATCC
9642, cis-carveol for $P$. simplicissinum, dehydrocarveol, and perillyl alcohol for $P$. putida.

From the results obtained in the fermentative screening, it is relevant to mention that, in spite of the low conversions obtained, cis-carveol and dehydrocarveol are precursors to carvone production, an important and high value compound for flavor industries (TECELÃO; van KEULEN; FONSECA, 2001).

\subsection{Evaluation of the presence of $\lim C$ gene}

The gene of $\mathrm{CDH}$ enzyme (Dichlorophenolindophenoldependent of carveol dehydrogenase), responsible for the conversion of carveol to carvone, was designed as $\lim \mathrm{C}$. This operon is related to the limonene degradation, specifically in the conversion of carveol to carvone step. The nucleotides sequence of $\mathrm{CDH}$ presented an ORF with 834 pairs of bases. To confirm that this gene is related to the route of limonene degradation, experiments of cloning and sequencing were performed by using the genetic material of Rhodococcus erythropolis DCL14 (van der WERF; SWARTS; de BONT, 1999).

In the present study, the amplification by PCR technique was performed by using PCR primers design from the sequence obtained in GenBank for the lim $\mathrm{C}$ gene. The results obtained in the amplifications made it possible to correlate the strains that present the fragment of interest and the results obtained in the fermentative screening.

The results of the amplification showed the presence of fragments between 700 and $900 \mathrm{bp}$, and the desired fragment was 834 bp (van der WERF; SWARTS; de BONT, 1999). The fragments were identified and are presented in Figure 2, numbers 1 to 7. These fragments were obtained in strains of Aspergillus niger ATCC 16404, Aspergillus niger ATCC 9642, Aspergillus oryzae ATCC 1003, Penicillium notatum ATCC 9478, Penicillium camembertii (CT) ATCC 4845, and Paecilomyces variotii ATCC 22319. These six strains were chosen through the visualization of agarose gel.

The obtained fragments close to $830 \mathrm{bp}$ (numbers 1 to 7) were isolated from agarose gel and purified for a new amplification (Figure 3). In this new gel, 9 fragments were taken, which were repurified and stocked for sequencing analysis (unpublished results).

Among the evaluated strains, it was not possible to correlate the microorganisms that presented the fragment of interest with the strains able to bioconvert limonene into carveol. The metabolic route of interest can be visualized in Figure 4, which shows the respective enzymes responsible for the studied steps.

Table 2. Microorganisms selected, end products and conversion obtained from the fermentative screening.

\begin{tabular}{|c|c|c|c|c|c|}
\hline \multirow[t]{2}{*}{ Microorganism } & \multicolumn{5}{|c|}{ Products (relative \%) } \\
\hline & a-terpineol & Cycle-hexanemethanol & Cis-carveol & Dehydrocarveol & Perillyl alcohol \\
\hline A. niger & $0.68 \pm 0.19$ & $0.64 \pm 0.27$ & - & - & - \\
\hline P. putida & - & - & - & $0.07 \pm 0.01$ & $0.31 \pm 0.01$ \\
\hline P. simplicissimum & - & - & $0.18 \pm 0.05$ & - & - \\
\hline
\end{tabular}




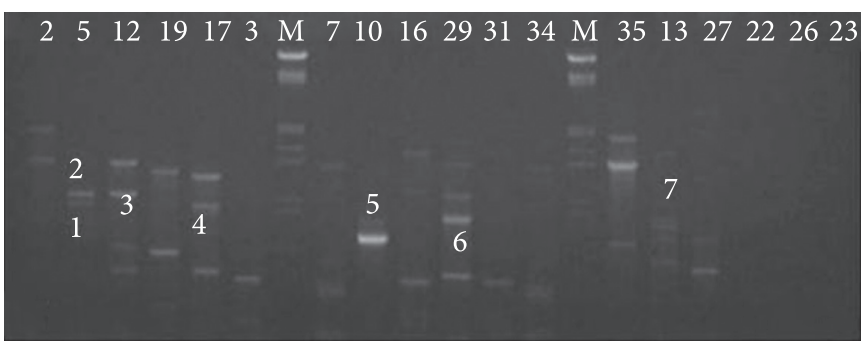

Figure 2. Agarose gel $(1,4 \%)$ demonstrative obtained with primers 1 and 2. Where $M$ is molecular size marker in base pairs (phase $\lambda$ DNA digested wit EcoRI and Hind III, Gibco, BRL); and 1 represents Aspergillus niger, 3 Penicillium citrinum ATCC 28752, 5 Aspergillus niger ATCC 16404, 7 Penicillium digitatum ATCC 26821, 10 Penicillium notatum ATCC 9478, 12 Aspergillus niger ATCC 9642, 13 Paecilomyces variotii ATCC 22319, 15 Penicillium brevicompactum, 17 Aspergillus oryzae ATCC 1003, 19 Aspergillus niger ATCC 1004, 29 Penicillium camembertii (CT) ATCC 4845, 31 Penicillium verrucosum, 33 Penicillium simplicissimum, 35 Penicillium duclauxi ATCC 9121, 21 Pseudomonas putida, Pseudomonas aeruginosa ATCC 27853, and 27 Candida sp. ATCC 34147.

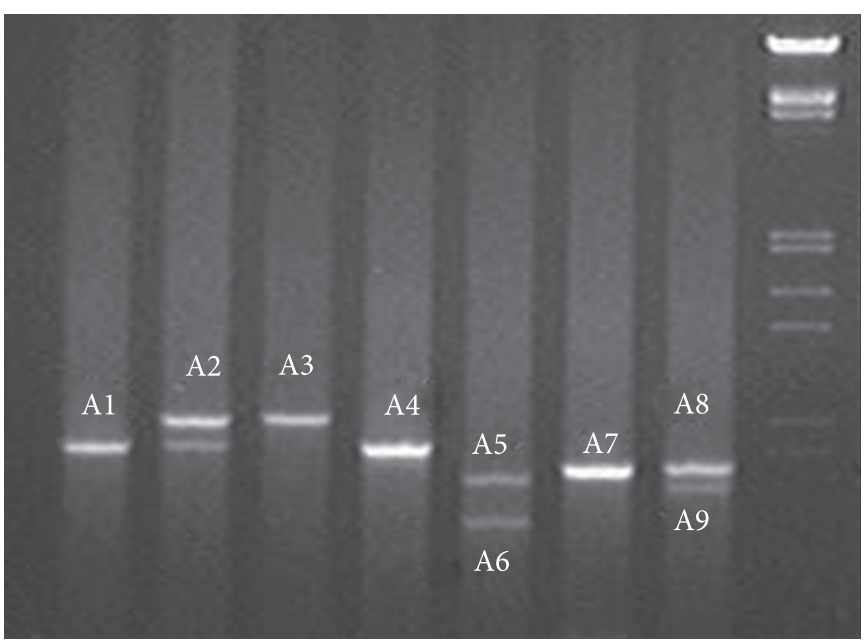

Figure 3. Agarose gel $(1,4 \%)$ demonstrative obttained after one second amplification with the microorganisms selected. $M$ is the molecular size marker in base pairs (phase $\lambda$ DNA digested wit EcoRI and Hind III, Gibco, BRL); and 5 Aspergillus niger ATCC 16404, 10 Penicillium notatum ATCC 9478, 12 Aspergillus niger ATCC 9642, 13 Paecilomyces variotii ATCC 22319, 17 Aspergillus oryzae ATCC 1003 and 29 Penicillium camembertii (CT) ATCC 4845. A1, A2, A3, A4, A5, A6, A7, A8, and A9 were used to identify the bands selected.

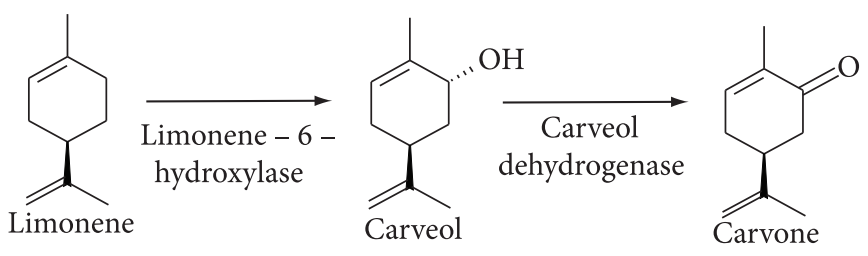

Figure 4. Biosynthetic route to carvone.

The strains of Penicillium simplicissimum and Pseudomonas putida were able to convert limonene into cis-carveol and dehydrocarveol, respectively. Nevertheless, these strains did not present the $834 \mathrm{bp}$ fragment, as it can be observed in Figure 2. Thus, we can conclude that these microorganisms do not present the gene responsible for the conversion of carveol to carvone.

The selected microorganisms that presented the fragment of approximately $800 \mathrm{bp}$ were not able to bioconvert limonene. From this result, we can suppose that these strains do not have the gene that codifies the enzyme responsible for the transformation of limonene to carveol. It can be said that they have only the gene able to convert carveol into carvone.

The results obtained in the bioconversion process and study of the $\lim C$ gene presence does not allow a correlation. Among the evaluated microorganisms, none was able to produce carvone, only products of limonene degradation route, showing that these strains do not have all the enzymes responsible for the steps of conversion of limonene to carvone.

\section{Conclusion}

The results obtained in the fermentative screening showed that 4 microorganisms were able to bioconvert the substrate limonene. The metabolites recovered were $\alpha$-terpineol and cycle-hexanemethanol (1,8-terpin) for A. niger, a-terpineol for A. niger ATCC 9642, dehydrocarveol, perillyl alcohol for P. putida, and cis-carveol for P. simplicissimum.

The amplification results obtained by using the PCR technique show the presence of fragments close to $800 \mathrm{pb}$, expected for the $\lim C$ gene. These fragments were obtained for the strains of Aspergillus niger ATCC 16404, Aspergillus niger ATCC 9642, Aspergillus oryzae ATCC 1003, Penicillium notatum ATCC 9478, Penicillium camembertii (CT) ATCC 4845, and Paecilomyces variotii ATCC 22319. The results obtained in the bioconversion process and evaluation of the $\lim C$ gene presence did not enable us to perform a correlation showing that these strains do not contain all enzymes responsible for the steps of conversion of limonene to carvone.

\section{Acknowledgements}

The authors are grateful for the financial support provided by CAPES (PROCAD), FUJB, CNPq, FINEP, and FAPERJ.

\section{References}

BALLAL, N. R.; BHATTACHARYYA, P. K. ; RANGACHARI, P. N. Microbial transformations of terpenes. Part XIV. Purification \& properties of perillyl alcohol dehydrogenase. Indian Journal of Biochemistry, v. 5, n. 1, p. 1-6, 1968.

BALLAL, N. R.; BHATTACHARYYA, P. K.; RANGACHARI, P. N. Perillyl aldeyde dehydrogenase from a soil Pseudomonas. Biochemical and Biophysical Research Communications, v. 29, n. 3, p. 275-280, 1967.

BAUER, K.; GARBE, D.; SURBURG, H. Common Fragrance and Flavor Materials: Preparation, Properties and Uses. 2 ed. Germany: Wiley-VCH, 1990.

CHANG, H. C.; ORIEL, P. Bioproduction of Perillyl alcohol and related monoterpenes by isolates of Bacillus stearothermophilus. Journal Food Science, v. 59, n. 3, p. 660-662, 1994.

DHAVALIKAR, J. C. R.; BHATTACHARYYA, P. K. Microbial transformations of terpenes. IX. Pathways of degradation of limonene 
in a soil Pseudomonad. Indian Journal of Biochemistry, v. 3, n. 3 , p. 158-164, 1966.

FREIRE, D. M. G.; GOMES, M. P.; BOM, S. P. E. Lipase production by a new promising strain of Penicillium restrictum. Brazilian Journal of Microbiology, v. 28, n. 1, p. 6-12, 1997.

KARP, F; CROTEAU, R. Analysis, Biochemistry, Biotechnology. In: SCHREIER, P.; GRUYER, W. DE (Ed.). Biollavor 87. Berlin: Walter de Gruyter, 1988. p. 173-198.

KIESLICH, K. et al. Transformation of Terpenoids. Progress in Essential Oil Research. In: INTERNATIONAL SYMPOSIUM ON ESSENTIAL OILS, 1, 1986. Proceedings... Germany: Walter de Gruyter, 1986. p. 14-18.

KRAIDMAN, G.; MUKHERJEE, B. B.; HILL, I. D. Conversion of D-limonene into an optically active isomer of a-terpineol by a Cladosporium species. Journal of Bacteriology, v. 63, p. 12-18, 1969.

KUBOTA, M. et al. Isolation and Functional Analysis of Cytochome P450 CYP153A Genes from Various Evironments. Bioscience, Biotechnology, and Biochemistry, v. 69, n. 12, p. 2421-2430, 2005.

LAWRENCE, B. M. Essential oils. Wheaton: Allured Press, 1981.

LUPIEN, S. et al. Regiospecific Cytochrome P450 Limonene Hydroxylases from Mint (Mentha) Species: cDNA Isolation, Characterization, and Functional Expression of (-)-4S-limonene3-hydroxylase and (-)-4S-limonene-6-hydroxylase. Archives of Biochemistry and Biophysics, v. 368, n. 1, p. 181-192, 1999.
ONKEN, J.; BERGER, F. G. Effects of R-(+)-limonene on submerged cultures of the terpene transforming basidiomycete Pleurotus sapidus. Journal of Biotechnology, v. 69, n. 2-3, p. 163-168, 1999.

ROEDER, V.; BRODA, P. Rapid preparation of DNA from filamentous fungi. Letters in Applied Microbiology, v. 1, n. 1, p. 17-20, 1987.

SAMBROOK, J.; FRITSCH, E. F; MANIATIS, T. Molecular cloning: a laboratory manual. 2 ed. New York: Cold Spring Harbor Laboratory, 1989.

SCHALK, M.; CROTEAU, R. A single amino acid substitution (F3631) converts the regiochemistry of the spearmint (-)-limonene hydroxylase from a C6- to C3-hydroxylase. Proceedings of the National Academy of Sciences, v. 97, n. 22, p. 11948-11953, 2000.

TECELÃO, C. S. R.; van KEULEN, F.; FONSECA, M. M. R. da. Development of a reaction system for the selective conversion of (-)-trans-carveol to (-)-carvone with whole cells of Rhodococcus erythropolis DCL14. Journal of Molecular Catalysis B, v. 11, p. 719-724, 2001.

TRUDGILL, P. W. Microbial metabolism by Pseudomonas In: GUNSALUS, I. C. The bacteria, a treatise on structure and function. Orlando: Academic Press, 1986. p. 483-425.

van der WERF, M. J.; SWARTS, H.; de BONT, J. A. M. Rhodococcus erythropolis DCL14 contains a novel degradation pathway for limonene. Applied and Environmental Microbiology, v. 65, n. 5, p. 2092-2102, 1999. 